\title{
Dziesięć lat z życia bibliotek polonijnych (1938-1948)
}

ozmaicie ukladaly się w przeszłości relacje między Polonią a Macierzą. Nawet obecnie, mimo znacznego postępu osiagnniętego w ostatnich latach, nie są one łatwe ani wolne od napięc. Jednak nikt już chyba nie ma wątpliwości, że rodaków zamieszkałych w kraju i za granicą łączyły i łączą rozliczne więzi i współzależności; przede wszystkim zaś wspólnota kulturowa. Dzieje Polonii są częścią historii polskiej, która bez tego istotnego elementu byłaby dalece niepełna. Analogicznie, obraz naszych bibliotek musi obejmować zbiory zarówno krajowe, jak też zgromadzone i przechowywane na obczyźnie. Ich losy często splatały się ze sobą bezpośrednio, a z reguły wzajemnie na siebie oddziaływały. Nie jest przypadkiem, że im trudniejsza była sytuacja książki na ziemiach polskich, tym więcej i większe powstawały biblioteki poza ich granicami, tym ważniejszą odgrywały one rolę. Wystarczy wymienić przykładowo pochodzące z epoki zaborów: Bibliotekę Polską w Paryżu, Batigniolska, Rapperswilską, a także księgozbiory Józefa M. Ossolińskiego i Czartoryskich. Podobnie działo się w okresie II wojny światowej. Kiedy pod okupacja niemiecką i sowiecką biblioteki krajowe nie tylko nie mogly wykonywać swoich normalnych funkcji, ale, co gorsza, były celowo i nieodwracalnie niszczone, Polonia przejęła inicjatywę. Lata 1938-1948 charakteryzuje ogromna aktywność tych środowisk.

Wojna wybuchła I września 1939 r., ale dla polskich instytucji kulturalnych podleglych wladzy hitlerowskiej (w III Rzeszy, Austrii) od 1938 r. datują się wzmożone represje prowadzące do ich calkowitej likwidacji jeszcze przed inwazją wrześniową!

Również data 8 czy 9 maja 1945 r. nie oznacza zakończenia wojennych wędrówek księgozbiorów polonijnych. Przeciwnie - otworzył się ich nowy, ważny rozdział, który doprowadził do względnej stabilizacji około $1948 \mathrm{r}^{2}$ Tak więc dekadę od jesieni 1938 do jesieni 1948 r. można uznać za zdeterminowaną losami wojennymi. Oczywiście, wpisuje się ona w ciąg wcześniejszych i późniejszych dziejów zbiorów polonijnych, ale równocześnie stanowi okres wyróżniający się własnymi specyficznymi cechami, zasługującymi na szczególną uwagę. 
Według współczesnych oszacowań w latach wojny opuściło Polskę ok. 5 milionów jej obywateli ${ }^{3}$, a więc mniej więcej co siódmy mieszkaniec ${ }^{4}$. Byli wśród nich wojskowi, jeńcy i więżniowie, robotnicy przymusowi, osoby deportowane i wysiedlone, uchodźcy. Znaczną część stanowili ludzie młodzi i w sile wieku, ale nie brakowalo też calych rodzin $\mathrm{z}$ dziećmi. Owa tak bardzo liczna rzesza była zróżnicowana pod wieloma względami: płci, wieku, wykształcenia, zamożności, pochodzenia i statusu społecznego, sytuacji życiowych, zdolności i zainteresowań. Istniała więc ogromna rozpiętość potrzeb czytelniczych, a w każdej grupie jawiły się one jako pilne i nieodzowne. Panoramę tę uzupełnia dawna Polonia, wcześniej osiadła na obczyźnie, której liczebność oceniona jest na ok. 9 milionów ${ }^{5}$. Wydatnie została ona zaktywizowana przez dramatyczne wydarzenia wojenne.

O księgozbiorach tych społeczności wiemy dużo i mało zarazem. Znane są oceny ogólne, dzieje najważniejszych placówek, szczegóły przytaczane w licznych opracowaniach poświęconych kulturze książki lub szerzej ujmowanej problematyce polonijnej. Literatura jest obszerna, zawierająca znaczne zasoby informacji, ale też wybiórcza, niespójna, często wtórna, powtarzajaca znane fakty, nie wolna od niedokładności, a nawet od sprzeczności ${ }^{6}$. Przede wszystkim zaś jest rozproszona. Trudno więc na jej podstawie zarysować całościowy obraz, odtworzyć rangę i znaczenie ówczesnego ruchu bibliotecznego. Dlatego w Biurze Pełnomocnika Rządu do Spraw Polskiego Dziedzictwa Kulturalnego za Granicą (w 2002 r. przekształconym w Departament Dziedzictwa Narodowego Ministerstwa Kultury) podjęte zostało zadanie przygotowania Informatora o bibliotekach polskich poza Krajem w latach 1938-19487. Ma on stanowić dopełnienie wydanych już tomów traktujących o wojennych losach księgozbiorów na ziemiach polskich ${ }^{8}$.

W wyniku kwerendy bibliograficznej autorzy zgromadzili przeszło czterysta pozycji zawierających informacje o księgozbiorach polonijnych w interesującym nas okresie. W kolejnych ok. czterystu znajdują się przyczynki do charakterystyki aktywności kulturalnej na obczyźnie, pośrednio tylko odnoszące się do tytułowego zagadnienia.

Najwięcej wiadomości dostarczaja, niestety nie nazbyt liczne, specjalistyczne opracowania dziejów książki polskiej na obczyźnie ${ }^{9}$ i zarysy monograficzne bibliotek $^{10}$. Nieporównywalnie liczniejsze od nich, a również cenne jest piśmiennictwo traktujące o poszczególnych skupiskach polonijnych ${ }^{\prime \prime}$, instytucjach i organizacjach $^{12}$. Materiał uzupełniający stanowią wspomnienia emigrantów oraz doniesienia prasowe. Rzadziej można spotkać dokumenty, np. sprawozdania i katalogi.

Niewiele nowych faktów odsłoniły dotąd poszukiwania w wybranych archiwach krajowych (m.in. w Warszawie, w Krakowie, w Cieszynie i w Pułtusku). Z pewnością obfity byłby plon kwerend archiwalnych prowadzonych systematycznie za gra- 
nica, na tych terenach, gdzie działały instytucje polonijne. Jednak takie badania pozostają obecnie poza moźliwościami zespołu autorskiego.

W tej sytuacji szczególnego znaczenia nabierają informacje zawarte w znakach proweniencyjnych pochodzących ze zbiorów polonijnych: superekslibrisach, ekslibrisach, pieczęciach, rękopiśmiennych notach wlasnościowych. Poświadczają one istnienie placówki, jej nazwę, czasem - adres. Jeśli zachowało się kilka kolejnych śladów, to dokumentują one drogę przebytą przez poszczególne egzemplarze. Jeśli wpisane są sygnatury (numery bieżące), to można na tej podstawie określić minimalną liczbę dzieł w danym księgozbiorze. Czasem dane te stanowią potwierdzenie lub uściślenie wiadomości uzyskanych z innych źródel, najczęściej jednak są dla nas jedynym sygnałem istnienia kolekcji. Najwięcej znaków proweniencyjnych udało się odnaleźć w Bibliotece Narodowej, Bibliotece Naukowej Zamku Królewskiego i Bibliotece Publicznej m. st. Warszawy oraz w Ośrodku Dokumentacji Wychodźstwa Polskiego w Pułtusku. Jest to oczywiście material wybiórczy, przypadkowy, a wobec mnogości tego rodzaju świadectw rozsianych po świecie, nawet nie reprezentatywny. Zwraca jednak uwagę na wartość owego specyficznego typu źródel bezpośrednich i wyznacza kierunek dalszych poszukiwań.

Niedostatek dokumentacji księgozbiorów polonijnych wynika nie tylko z koniecznych ograniczeń rozmiarów kwerendy, ale przede wszystkim z charakteru samej materii. Biblioteki rozrzucone były na rozległych przestrzeniach niemal wszystkich kontynentów, od obu Ameryk, przez Australię, Afrykę, po Europę i Azję. Były zdecentralizowane, zakładane i likwidowane w miarę zmiennych potrzeb użytkowników, przenoszone wraz z nimi, reorganizowane, łączone i dzielone. Przeważnie były to niewielkie księgozbiory służące bieżącym celom edukacyjnym, ideowym i rekreacyjnym, prowadzone przez aktywistów-amatorów, na marginesie innych ich zatrudnień, bez konieczności ani możliwości profesjonalnej obsługi bibliotekarskiej. Fakt ten nie pomniejsza ich społecznego ani kulturalnego znaczenia. Przeciwnie, żywiołowość powstawania i funkcjonowania placówek bibliotecznych (stałych, „okrężnych”, wysyłkowych) wskazuje na dojmujący „głód” książki, który musiał być zaspokajany tak, jak pozwalały okoliczności. Bardzo to jednak komplikuje pracę historyków.

Nieco pomyślniej kształtuje się sytuacja w odniesieniu do większych, stabilnych książnic polonijnych tworzonych i wzbogacanych nie tylko z myślą o bieżących potrzebach czytelniczych emigrantów, lecz również o gromadzeniu świadectw kultury narodowej, dokumentacji losów Polski i Polaków, o przygotowaniu podstawowych zasobów piśmienniczych dla społeczenstwa przyszłego niepodległego państwa. Takie cele stawiali twórcy np. Biblioteki Polskiej w Londynie, Biblioteki Polskiego Instytutu Naukowego w Ameryce, Biblioteki Polskiego Instytutu Naukowego w Montrealu i innych ${ }^{13}$. 
Jako kolekcje polonijne uznawane są w Informatorze te zbiory biblioteczne, które w latach 1938-1948 znajdowały się poza granicami II Rzeczypospolitej, a należały do organizacji lub osób prywatnych identyfikujących się z narodowością i kulturą polską. Obok własności emigrantów zaliczają się więc do nich także księgozbiory polskiej ludności autochtonicznej zamieszkującej tereny pozostające pod władzą obcych państw, gdzie traktowani oni byli jako mniejszości narodowe (III Rzesza, Czechosłowacja, Litwa, Łotwa, Rumunia).

Jak już podkreślano, zgromadzone materiały dalekie są od kompletności. Stanowią jednak podstawę najobszerniejszego z dotychczas znanych spisu księgozbiorów polonijnych pochodzacych z okresu wojny i okupacji. Wykaz obejmuje opisy przeszło tysiąca zidentyfikowanych bibliotek na różnym szczeblu szczegółowości: od w miarę dokładnych po wręcz sygnalne. Dopełnieniem opisów indywidualnych są zestawienia zbiorcze wydobyte $\mathrm{z}$ dostępnych opracowań ${ }^{14}$.

Informator, przy wszystkich niedostatkach materialowych, wyraźnie ukazuje bogactwo i dynamikę polonijnego ruchu na rzecz gromadzenia zbiorów. Wśród bardzo wielu rodzajów inicjatyw zwracają uwagę przede wszystkim biblioteki:

- dawnych i nowo powstałych skupisk polonijnych,

- polskich agend rządowych na obczyźnie,

- jednostek militarnych i szpitali wojskowych,

- obozów dla jeńców wojennych oraz internowanych,

- obozów i zgrupowań uchodźców cywilnych,

- księgozbiory prywatne.

Wymienione grupy nie są rozłączne ani nie wyczerpują wszystkich istniejących wówczas wariantów sytuacyjnych. Służą jedynie bliższej charakterystyce zjawiska. W każdej kategorii istniały znaczne rozpiętości od niewielkich, okazjonalnych i dość przypadkowych zbiorków do wielotomowych, cennych kolekcji o trwałych wartościach i ponadlokalnym oddziaływaniu.

Dążność do zakładania własnych bibliotek nie pojawiła się dopiero z wojenną falą emigrantów. Charakteryzowała ona również poprzednie pokolenia osadników. Gdziekolwiek zbierze się większa gromadka Polaków, tam zawsze znajdzie się ktoś, kto podejmie inicjatywę do założenia czytelni lub biblioteki polskiej, która póżniej stopniowo rozwija się wraz ze wzrostem kolonii i dochodzi nieraz do bardzo poważnych rozmiarów - pisał w 1912 r. Florian Znaniecki ${ }^{15}$. To spostrzeżenie wybitnego socjologa znajduje potwierdzenie również w praktyce późniejszych czasów.

W okresie międzywojennym księgozbiory polonijne były już bardzo liczne, szacowane na dziesiątki, a nawet setki w każdym kraju, do którego dotarli emigran$\mathrm{ci}^{16}$. Były też ogromnie rozproszone terytorialnie i zróżnicowane pod względem własności. Zwykle mieścily się przy szkołach, klubach, parafiach i klasztorach. Należały do poszczególnych instytucji, a także - i to może przede wszystkim - do po- 
lonijnych organizacji (społecznych, charytatywnych, kulturalno-oświatowych) stawiających sobie za cel utrzymanie i umocnienie polskiej tożsamości narodowej. Przeważały więc księgozbiory szkolne i powszechne, czasem sprofilowane - przeznaczone dla kół muzycznych czy teatralnych, niekiedy dla korporacji zawodowych (np. polskich nauczycieli czy lekarzy). Pilnie przestrzegano odrębności organizacyjnych oraz ideologicznych. Niekiedy w jednej niewielkiej miejscowości egzystowało kilka osobnych, drobnych zbiorkow. Władzom II Rzeczypospolitej nie udawały się akcje scalania ani ewidencjonowania tych placówek. Jednak starały się o ich wzmocnienie poprzez dofinansowanie oraz zaopatrywanie w książki.

Bezpośrednio odpowiednim agendom rządu polskiego podlegały biblioteki placówek dyplomatycznych i założona w 1936 r. Biblioteka Muzeum Polski Współczesnej w Rapperswilu. Polska Akademia Umiejętności sprawowała opiekę nad Biblioteką Polską w Paryżu (założona 1838 r.) i Biblioteką Polską w Rzymie (założona 1921 r.).

Najważniejszą rolę odgrywały jednak działające na obczyżnie ponadlokalne organizacje polonijne utrzymujące rozgałęzione sieci własnych, stałych instytucji kulturalnych o znacznym potencjale materialnym i programowym. Należały do nich m.in. Związek Polaków w Kanadzie, Związek Narodowy Polski i Zjednoczenie Polskie Rzymsko-Katolickie w Stanach Zjednoczonych oraz Związek Polaków w Niemczech.

Agresja hitlerowska zasadniczo zmieniła sytuację bibliotek polskich. Na terenach objętych władzą III Rzeszy zostały one zamknięte, a zbiory skonfiskowane i w przeważającej części zniszczone. Tak stało się w latach 1938-1939 w Niemczech, Austrii i Czechoslowacji, a w 1940 r. w zajętych krajach Europy Zachodniej (m.in. Francja $^{17}$, Belgia, Holandia). Znacznie dłużej, niemal do końca wojny, działały polskie instytucje kulturalne na Węgrzech i w Rumunii. Natomiast w krajach alianckich i neutralnych nastapiło znaczne ożywienie polonijnego ruchu bibliotecznego ${ }^{18}$.

Rząd polski na emigracji (początkowo we Francji, od 1940 r. w Wielkiej Brytanii), będąc kontynuatorem polskich władz przedwrześniowych i dysponując dotacjami finansowymi państw sojuszniczych, organizował i wspomagał biblioteki polonijne $^{19}$. Pod jego egida pozostawały np. w latach 1939-1945 Biblioteka Rapperswilska oraz Biblioteka Polska w Londynie ${ }^{20}$, Biblioteka Polskiego Ośrodka Naukowego w Londynie (zainicjowanego na przełomie 1939/1940 r.), a przede wszystkim zbiory placówek dyplomatycznych na obczyźnie. Agendy rządu udzielały pomocy finansowej oraz zaopatrywały w książki rozliczne inne akcje kulturalne i naukowe (np. Polski Instytut Naukowy w Ameryce założony w 1941 r. i jego oddzial w Kanadzie założony w 1943 r.).

Znacznie zaktywizowały się też dawne książnice polonijne. Wzrastały ich zbiory, wprowadzono nowe formy działalności (np. komplety ruchome, wypożyczalnie 
wysyłkowe). Dzięki licznym darowiznom zasoby biblioteczne wzbogacane byly archiwalnymi i muzealnymi (np. Biblioteka, Archiwum i Muzeum Zjednoczenia Polskiego Rzymsko-Katolickiego w Chicago, założona w 1913 r.; Biblioteka Związku Narodowego Polskiego - później pod nazwą Biblioteka i Muzeum - też w Chicago, założona w 1892 r.). Tendencja owa nie omijała nawet niewielkich placówek, np. Biblioteka Parafii św. Stanisława Kostki w Nowym Jorku (założona w 1926 r.), w 1942 r. otworzyła muzeum w osobnej sali i zatrudniła tam specjalnego pracownika. Nb. w 1946 r. księgozbiór biblioteczny liczył ok. 3000 tomów, a w 1980 r. już tylko 1500 . Trzeba podkreślić, że stabilne biblioteki polonijne spełniły ważną rolę, po wojnie przyjmujac i przechowując liczne i nieraz bardzo cenne spuścizny po likwidowanych instytucjach, organizacjach oraz działaczach polonijnych.

Wraz z napływem kolejnych fal uchodźców powstawały nowe księgozbiory, albo wbudowane w dawne struktury polonijne (dodatkowe sekcje, oddziały), albo zupełnie od nich niezależne. Taką specyficznie wojenną kategorią stały się biblioteki obozów jenieckich oficerskich (oflagi) i podoficerskich (stalagi). Powstały one glównie na terenie Niemiec i Austrii, sporadycznie - w Związku Radzieckim. Ogromną spełniały rolę w kształceniu oraz umacnianiu sił psychicznych więźniów ${ }^{21}$. Gromadzone i utrzymywane $\mathrm{z}$ wielkim staraniem, kosztem licznych wyrzeczeń, niekiedy dochodziły do znacznych rozmiarów i wysokiego stopnia organizacji; np. Centralna Biblioteka Obozowa w Murnau, założona w 1939 r., pod koniec wojny liczyła 23206 tomów (15 206 - dział ogólny, 8000 - naukowy). Zaopatrywała ona w książki inne skupiska jenieckie i przejmowała zbiory z likwidowanych oflagów. Biblioteka Obozowa w Dobiegniewie (Woldenberg), założona w 1941 r., zawierała w 1944 r. 30 tysięcy, a według innych źródeł nawet 50 tysięcy tomów. Oprócz działu ogólnego utrzymywała specjalistyczne zestawy m.in. dla kół: nauczycielskiego, kultury wsi i samorządowców. Funkcje kierownicze sprawowały Zarząd Bibliotek Obozowych i Rada Biblioteczna. W Bibliotece Oflagu w Bornym Sulinowie (Gross Born Redderitz-Westfalenhof) było w 1944 r. ok. 45000 tomów podzielonych na działy: beletrystyki, naukowy i pedagogiczny. Inne biblioteki obozowe były mniejsze, ale równie pieczołowicie prowadzone przez jeńców.

Nieporównanie korzystniejsze warunki panowały w obozach dla internowanych. Np. w Szwajcarii działały polskie obozy uniwersyteckie we Fryburgu, Herisau i Winterthur, wyposażone we własne księgozbiory, gdzie skoszarowani uczestnicy mogli zdobywać wyższe wykształcenie na tamtejszych uczelniach. Od $1940 \mathrm{r}$. organizacje polonijne i międzynarodowe przesyłały komplety dzieł do ponad czterdziestu obozów dla internowanych.

Przez cały okres wojenny i jeszcze kilka lat póżniej intensywnie prowadzone było polskie szkolnictwo w Wielkiej Brytanii, wyposażone w niezbędne pomoce naukowe. W latach 1940-1949 funkcjonowała np. Biblioteka Polskiego Wydziału Le- 
karskiego przy Uniwersytecie w Edynburgu oraz w latach 1943 - 1948 Biblioteka Komisji Akademii Studiów Medycyny Weterynaryjnej w Royal (Dick) Veterinary College. W okresie 1942-1946 pracowała Biblioteka Polskiej Szkoły Architektury przy Uniwersytecie w Liverpoolu; później przeniesiona do Londynu, zlikwidowana została w 1954 r.; Biblioteka Polskiego Wydziału Prawa przy Uniwersytecie w Oxfordzie czynna byla w latach 1944-1947. Wcześniej, bo od 1941 r., wysyłała książki uczniom i studentom służącym w wojsku Biblioteka Naukowa Zrzeszenia Studentów Polskich Zagranicą z Edynburga. Równocześnie, też od 1941 r. istniała Biblioteka Nauczania Korespondencyjnego w Glasgow (w latach 1954-1957 w Londynie).

Więcej było księgozbiorów szkół średnich przeznaczonych dla młodzieży męskiej i żeńskiej, wojskowej i cywilnej. Najdłużej, bo do 1957 r., działała Biblioteka Gimnazjum i Liceum Męskiego im. M. Kopernika, założona w 1946 r. w Riddlesworth, w 1948 r. przeniesiona do Bottisham k. Cambridge. Wówczas liczyła ok. 50000 tomów, przejęła bowiem zbiory z likwidowanych innych bibliotek szkolnych z Anglii i Bliskiego Wschodu.

Ważną rolę w organizacji i utrzymywaniu książnic wszelkich typów odgrywał od 1940 r. mecenat wojskowy ${ }^{22}$. Szczególnie intensywne formy przybrał on od 1942 r., kiedy rozpoczął się exodus wyprowadzonej z ZSRR Armii Polskiej i towarzyszących jej rzesz uchodźców cywilnych. Na trasie wędrówek poprzez Iran, Irak, Transjordanię, Palestynę, Liban do Italii powstawały obozy dla uciekinierów, a w nich m.in. przedszkola i szkoły, świetlice i biblioteki. Później dotarły one także do Afryki i Ameryki ${ }^{23}$.

Prężne ośrodki działały m.in. w Palestynie, gdzie w latach 1942-1947 mieścito się Dowództwo Szkól Junackich na Bliskim Wschodzie, które prowadziło sieć szkól różnych typów i stopni. Wszystkie one zaopatrzone byly w księgozbiory. Centralna Biblioteka Naukowa DSJ, ulokowana w miejscowości Barbara, w 1947 r. liczyła ok. 19000 poz. W tymże roku została przeniesiona do Wielkiej Brytanii, a w 1948 r. jej zbiory, podobnie zresztą jak zasoby wielu innych jednostek wojskowych i uchodźczych, przejęło Stowarzyszenie Polskich Kombatantów. W Londynie w 1957 r. znalazła się m.in. ciekawa Biblioteka Instytutu Bliskiego i Środkowego Wschodu założona w 1946 r. w obozie Quassassin w Egipcie, w 1948 r. przeniesiona do Jerozolimy (liczyła wówczas ok. 1500 poz.).

Również do Anglii zawędrowala w 1947 r. Centralna Biblioteka Wojskowa Towarzystwa Wiedzy Wojskowej II Korpusu (ok. 8000 tomów). Inny zbiór ksiazżek II Korpusu Armii Polskiej zostal przywieziony do Ottawy przez byłych żołnierzy, którzy założyli w Kanadzie Stowarzyszenie Polskich Kombatantów.

Po zakończeniu działań wojennych nastapiły kolejne przemieszczenia ludności polskiej. Powstaly wtedy m.in. tymczasowe obozy dla przesiedleńców (tzw. di- 
pisów - displaced persons). W nich też tworzone były biblioteki. W samej Austrii w 1946 r. funkcjonowało 29 takich placówek ${ }^{24}$.

Nie sposób wymienić najważniejsze nawet instytucje i organizacje prowadzące wśród Polonii działalność kulturalno-oświatową w czasie wojny i po jej zakończeniu. Książki do bibliotek dostarczały agendy rządu londyńskiego, armii, stowarzyszeń polonijnych oraz organizacji międzynarodowych (przede wszystkim YMCA i Czerwony Krzyż). Ogromny też był wkład ofiarodawców prywatnych, zarówno Polaków, jak i obcokrajowców. W zbiorach różnych typów i klas znalazły się publikacje, archiwalia i muzealia liczone łącznie w milionach jednostek. Rozmaicie ksztaltowały się ich powojenne losy. Na swoich miejscach przetrwaly większe instytucje i one też przejmowały zasoby likwidowanych placówek (np. Biblioteka Polska w Londynie, Biblioteka Instytutu Naukowego J. Piłsudskiego w Nowym Jorku, Biblioteka Polonijnych Zakładów Naukowych Seminarium Polskiego w Orchard Lake). Bardzo liczne kolekcje trafiły do zbiorów publicznych w krajach osiedlenia właścicieli. Pokaźna liczba druków i rękopisów przekazana została do Polski (np. księgozbiór Biblioteki Rapperswilskiej w latach 1946-1951; ok. 10000 tomów z Biblioteki Polskiej w Paryżu w 1947 r.; ponad 15000 pozycji z Biblioteki Polskiej w Londynie w latach 1945-1946; ok. 20000 druków, rękopisów i nut z Oflagu Borne Sulinowo w 1945 r.).

Księgozbiory okazjonalne, ruchome, przeznaczone dla grup lączonych czasowo (np. biblioteki obozowe, szpitalne, jednostek wojskowych) upadały wraz z rozwiązaniem tych skupisk społecznych. Zwykle, spełniwszy swe zadanie, ulegały rozproszeniu i częściowej lub całkowitej zatracie.

Śledzenie powikłanych kolei losów bibliotek polonijnych prowadzi do bardzo pouczających wniosków, czasem gorzkich, czasem przeciwnie - budujących. Ale to już zupełnie inna historia.

Osobny, bardzo istotny problem integralnie wpisany w dzieje polskiej książki na obczyźnie stanowią kolekcje prywatne. Jednak pobieżne nawet jego przedstawienie przekracza ramy niniejszego szkicu. Znajduje natomiast miejsce w zapowiadanym Informatorze.

\section{Przypisy}

1 J. Wróblewski, Biblioteki polskie na Warmii, Mazurach i Powiślu w latach 1881-19.59, Olsztyn 1968, s. 102-106; idem, Z dziejów bibliotekarstwa polskiego na Pograniczu i Kaszubach, „Przegląd Historyczno-Oświatowy" 14, 1971, nr 4, s. 614-615; idem: Ostatni rok dziatalności Centralnej Biblioteki Polskiej w Niemczech - Oddziat: Prusy Wschodnie, „Komunikaty Mazursko-Warmińskie” 1968, nг I, s. $119-131$. 
2 O.S. Czarnik, Opieka, wsparcie czy samopomoc? Z problemów mecenatu kulturalnego na obczyźnie, w: Z dziejów mecenatu kulturalnego w Polsce, red. J. Kostecki. Warszawa 1999 s. 277-289; Z. Gaca-Dąbrowska, Tropami organizowania sieci bibliotek polskich na obczyzinie (Dziatalność biblioteczna Stowarzyszenia Polskich Kombatantów), „Roczniki Biblioteczne” 36, 1992, z. 1-2, s. 212-231.

${ }^{3}$ O.S. Czarnik, Opieka..., s. 277; A. Brożek: Polskie biblioteki ludowe na emigracji, „Biuletyn Biblioteki Jagiellońskiej" 34-35, 1984 -1985, s. 164.

${ }^{4}$ Wg Matego Rocznika Statystycznego 1939 (Warszawa 1939 s. 10), ludność Polski w 1939 r. wynosila 35,1 miliona.

${ }^{5} \mathrm{~J}$. Albin, Z dziejów bibliolek i ksiażki polskiej za granica w latach 1919-1939, „Roczniki Biblioteczne" 21, 1977, z. 1/2, s. 310.

${ }^{6} \mathrm{~W}$ odniesieniu do biografistyki polonijnej podobną charakterystykę przedstawił B. Klimaszewski, III Sympozjum Biografistyki Polonijnej, Rzym 1998, „Przegląd Polonijny” 21, 1999, z. 1, s. 105. Por. też charakterystykę bazy żródlowej w M.A. Supruniuk, Archiwa pisarzy i instytucji emigracyjnych w badaniach nad literaturq wychodzistwa polskiego, w: Pouroty w zapomnienie. Dekada literatury emigracyjnej 1989-1999, red. B. Klimaszewski, W. Ligęza, Kraków 2001, s. 61-78.

${ }^{7}$ Opublikowanie Informatora planowane jest na rok 2003. Pani dyrektor Izabelli Danis oraz współautorom opracowania, pani dr Urszuli Paszkiewicz i panu mgr. Januszowi Szymańskiemu, dziękuję za uprzejme wyrażenie zgody na wykorzystanie materiałów zawartych w kartotekach. Na nich oparty zostal niniejszy artyku\}.

${ }^{8}$ Straty bibliotek w czasie II wojny światowej w granicach Polski z 1945 roku. Wstępny raport o stanie wiedzy, red. A. Mężyński. Warszawa 1994; Biblioteki na wschodnich ziemiach II Rzeczypospolitej. Informator, red. B. Bieńkowska, Poznań 1998; Informator o siratach bibliotek i księgozbiorów domowych ha terytoriach polskich okupowanych w latach 1939-1945 (bez ziem wschodnich), Red. B. Bieńkowska, Poznań 2000.

${ }^{9}$ Obok cytowanych powyżej, przykładowo można wymienić publikacje: M. Danilewicz-Zielińska, Ksiqżka i czytelnictwo polskie w Wielkiej Brytanii, Warszawa 1996; K. Zieliński, Ksiażka w obozach polskich jeńcow wojennych podczas II wojny światowej, „Rocznik Biblioteki Narodowej” 16, 1980, s. 219-239; J. Wróblewski, Rola ksiqżki w obozach jenieckich w czasie II wojny świalowej, „Roczniki Biblioteczne” 36, 1992, z. 1/2, s. 233-266; M. Andrzejewski, Biblioteki, czytelnictwo i działalność wydawnicza internowanych w Szwajcarii żotnierzy 2 Dywizji Strzelców Pieszych, „Roczniki Biblioteczne” 26. 1982, z. I/2, s. 129-143; A. Klossowski, Instylucje ksiqżki polskiej i księgozbiory polskie na obczyżnie, „Acta Universitatis Nicolai Copernici”. Bibliologia II-III. Nauki Humanistyczno-Spoleczne 1998, z. 328, s. $89-141$.

${ }^{10}$ Np. M. Czechowski, Biblioreka Polska w Londynie, „Rocznik Biblioteki Narodowej” 21/22, 1985/1986, s. 167-192; Biblioteka Polska w Londynie w latach 1942-1992, Londyn 1993; F. Pulaski: Biblioteka Polska w Paryżı w latach 1893-1948. Paryż 1948; A. Mężynski: Biblioteka Polska w Paryżu. Rys historyczny, zbiory, dzieñ dzisiejszy, „Przegląd Biblioteczny” 51, 1983, z. 1, s. 13-25; F. Szymiczek, Biblioteka polskiego gimnazjum w Bytomiu (1932-1939), Opole 1965; A. Szabat, Biblioteka Stacji Naukowej PAN w Rzymie, „Przegląd Biblioteczny” 66, 1998, z. 2/3, s. 175-190.

" Np. J. Albin, Polacy w Jugostawii, Lublin 1983; M. Dubicki, Polscy uchodźcy w Rumunii 1939-1945, Warszawa 1990; U. Kaczmarek, Na węgierskiej ziemi. Rzecz o Polonii węgierskiej, Poznań 1999; W. Eder, Dzieje Polonii belgijskiej 1919-1987 (w zarysie), Warszawa 1999; M. Paradowska, Polacy w Meksyku i Ameryce Srodkowej, Wroclaw 1985.

${ }^{12}$ Np. J. Cisek, Instytut Józefa Pilsudskiego w Ameryce i jego zbiory, Warszawa 1997; B. Czaykowski, Polski Ośrodek Naukowy (Polish Research Centre) 1940-1960, Londyn 1961; R. Nir, Stulecie Pol- 
skiego Seminarium w Orchard Lake w Stanach Zjednoczonych 1885-1987, Orchard Lake 1989; E. Kruszewski, Polski Instytut Źródfowy w Lund (1939-1972). Zarys historii i dorobek, Londyn-Kopenhaga 2001; M. Haiman, Zjednoczenie Polskie Rzwmsko-Katolickie w Amervece 1873-1948, Chicago 1948; B.T. Łaszewski, $Z$ wojskowych szeregów do życia cywilnego. Historia powslania i pierwsżych pięciul lal dzialalności Stowarzyszenia Polskich Kombatantów 1945-1950, New York 1984; Zwiazek Narodowy Polski. Zarys historyczny 1930-1983, red. M. Brodzka, Toronto 1994.

${ }^{13}$ Por. J.S. Morkowski, Pót wieku instytucji kultury polskiej na Zachodzie, „Czasopismo Zakładu Narodowego im. Ossolinskich" 1997, z. 8, s. 19-32.

${ }^{14}$ Wskazują one na ogromne dysproporcje istniejące między stanem faktycznym a zarejestrowanym w Informatorze. Np. wediug danych pochodzących ze sprawozdan Związek Patriotów Polskich w ZSRR zorganizowal w okresie wojny ok. 640 bibliotek (E. Trela, Edukacja dzieci polskich w Zwiqzku Radzieckim w latach 1941-1946, Warszawa 1983, s. 165; nb. inne opracowania podają wyższe liczby); Polski Czerwony Krzyż utrzymywał w 1943 r. w armii i w szpitalach 409 bibliotek stałych i ruchomych (Sprawozdania z dziatalności Polskiego Czerwonego Krzyża za okres od 13 VIII 1940 do 31 XII 1943. Londyn 1944, s. 18, 64); w 1939 r. funkcjonowalo w USA 171 bibliotek Zwiazku Narodowego Polskiego (Pamiętnik Sejmu XXVIII Z. N. P. w Detroit. Mich. od 10-go do 16-go września 1939, b.m.r. s. 34); Towarzystwo Pomocy Polakom (Delegatura w Niemczech) prowadzilo w 1947 r. w obozach, szpitalach i kompaniach wartowniczych 191 bibliotek (Towarzıstwo Pomocy Polakom. Sprawozdanie z działalności poza Wielkq Brylaniq za rak 1947, Londyn 1948 s. 22). W redakcyjnej kartotece odnotowane są tylko pojedyncze placówki każdej z wymienionych organizacji.

${ }^{15}$ Cytuję za A. Brożek, Polskie biblioteki..., s. 167.

16 Ogólną charakterystykę intensywności ruchu bibliotecznego i szacunkowe, cząstkowe dane liczbowe przynoszą opracowania: A. Brożek, Polskie biblioteki... passim; J. Albin, $Z$ dziejów... passim; M.J. Lech, Próby centralnej koordynacji akcji organizowania bibliotek polskich na emigracji (1929-1939), „Problemy Polonii Zagranicznej” 1, 1974, nr 9, s. 119-139.

${ }^{17}$ W czerwcu 1940 r. zamknięta została m.in. Biblioteka Polska w Paryżu. Zbiory, których zarząd nie zdołał wcześniej ukryć, Niemcy skonfiskowali i wywieżli. Po wojnie powróciły do Francji ze znacznymi stratami. Zniszczeniu uległy polonijne biblioteki powszechne. Natomiast księgozbiory prywatne w większości udało się właścicielom przechować.

${ }^{18}$ Wyjątek stanowiła Brazylia, gdzie na skutek wydanych w latach 1937-1938 dekretów nacjonalizacyjnych na kilka lat zamarla dzialalność instytucji polonijnych. Stopniowo ich odradzanie następowało po 1945 r. Zob. M. Krasicki, Sytuacja zbiorowości polonijnych i innych griı imigracyjnych w Brazylii w dobie ustaw nacjonalistycznych prezydenta Vargasa, „Przegląd Polonijny” 5, 1979, z. 1, s. 43-58; M. Kula, Polonia brazylijska, Warszawa 1981, s. 184-192.

${ }^{19} \mathrm{Na}$ temat organizacji i finansowania kultury polonijnej, zob. O.S. Czarnik, Opieka..., s. 277-298.

${ }^{20}$ Utworzona została w 1943 r. z polączenia istniejących od 1942 r. zbiorów Urzędu Oświaty i Spraw Szkolnych w Londynie oraz Funduszu Kultury Narodowej.

${ }^{21}$ Zob. J. Wróblewski, Rola ksiażki..; K. Zieliński, Ksiqżka w obozach...; V. Rezler-Wasielewska, Dzialalność naukowo-oświatowa polskich jeńców wojennych w niemieckich i radzieckich obozach podczas II wojny światowej, Opole 2001.

22 O.S. Czarnik, Opieka..., s. 285-287.

${ }^{23}$ Np. w Santa Rosa w Meksyku w latach 1944-1947 dzialała Biblioteka Osiedla Polskiego dla Uchodźców. W 1946 r. bylo tam zgromadzone ok. 14000 książek. W trakcie likwidacji zbiorów 8150 tomów przekazano do Polski, resztę do bibliotek polonijnych w Meksyku i w USA oraz osobom prywatnym.

${ }^{24}$ A. Pilch, Losy Polaków w Austrii po drigiej wojnie światowej 1945-1955, Wroclaw 1994, s. 142-144. 